\section{Ancient bone DNA amplified}

SIR-Although the extraction and characterization of DNA from ancient soft-tissue remains is possible $\mathrm{e}^{1-3}$, it is the application of these techniques to the far more abundant remains of bone and teeth that will provide the opportunity for large-scale population sampling. We report the successful extraction and amplification of DNA from human bones between 300 and 5,500 years of age.

Typically, we can recover $5-10 \mu \mathrm{g}$ of DNA from $2 \mathrm{~g}$ of powdered cortical bone. Although the DNA is degraded it is often possible to recover material of high molecular mass. Figure 1 shows DNA extracted from six well-preserved human bone samples after separation by agarose gel electrophoresis. Our results indicate that the preservation of DNA in a bone depends less on the age of the specimen than on the burial conditions of the skeleton.

We used the extracted DNA as a template for the polymerase chain reaction (PCR), which is ideal for amplifying DNA in biological samples with little or degraded DNA ${ }^{4}$. To monitor the amplification of contaminant $\mathrm{DNA}^{5}$ we performed control extractions and PCR, and sequenced fragments of the amplified DNA.

Some of the ancient DNA extracts, including the majority of the 19 seventeenth-century Abingdon bone samples examined, had an unknown contaminant that inhibited PCR, but inhibition was overcome in most cases by adding bovine serum albumin ${ }^{3}$. Our PCR amplifications were performed with only 2 units of Taq polymerase, as opposed to the 12.5 units of enzyme that was required for amplification of a DNA fragment from 7,000-yearold human brain tissue ${ }^{3}$.

Aliquots of $2-5 \%$ of the extract from $2 \mathrm{~g}$ of bone were used for PCR with pairs

FIG. 1 Agarose gel electrophoresis of DNA extracted from bone samples of six individuals. Lane 1, DNA size markers; lanes 2, 3 and 4, DNA extracted from three femurs from a seventeenth-century English Civil War cemetery in Abingdon, Oxfordshire; lane 5, DNA from male humerus (radiocarbon date $750 \pm 80 \mathrm{yr}$ $\mathrm{BP}$, Anglo Saxon-medieval cemetery, Abingdon; lane 6. DNA from the skull of a child (radiocarbon date $4,810 \pm 80 \mathrm{yr} \mathrm{BP}$, Maiden Castle, Dorset); and lane 7, DNA from a human femur (radiocarbon date about $5,450 \mathrm{yr} \mathrm{BP}$, cave burial, Wadi Mamed, Judaean Desert).

METHODS. The dirt and outside surfaces of the bone samples were removed by shotblasting with fine aluminium oxide grit. The bone fragments were powdered in a Spex freezer mill refrigerated with liquid nitrogen, and then stored at $-20^{\circ} \mathrm{C}$. After decalcifica-

tion of $2 \mathrm{~g}$ powdered tissue with $0.5 \mathrm{M}$ EDTA, $\mathrm{pH} 8.5$, the DNA was extracted by the method of Maniatis et al. ${ }^{9}$ and concentrated by centrifugation-driven dialysis using Centricon 30 microconcentrators (Amicon). DNA samples $(10 \mu \mathrm{l})$, representing 5-10\% of the DNA extracted, were loaded on a $1 \%$ agarose gel. After electrophoresis, the gel was stained with ethidium bromide and photographed under ultraviolet light. 300-year-old femur; 4 and 8 , modern DNA; 5 of primers specific to various parts of the mitochondrial genome. Amplifications of 121-base-pair (bp) and 205-bp fragments of mitochondrial DNA were reproducible with extracts of different bones, and with different extracts of the same bone, including the 5,450-year-old specimen.

FIG. 2 PCR amplifications of mtDNA from ancient and modern DNA. Lane 1, DNA size markers in multiples of $123 \mathrm{bp}$; lanes $2-5$, 205-bp fragment of the MTND4 gene obtained with primer 2 (see ref. 7 ) and primer 4 (mtDNA bases 11,211-11,230); lanes 6-9, 121-bp fragment obtained with primers $A$ and $B$ (see ref. 10). Templates: lanes 2 and 6, DNA from 750 -year-old humerus; 3 and 7 , DNA from and 9 , blank controls with no DNA.

METHODS. PCR amplifications were carried out by the method of Perkin Elmer Cetus in $25-\mu$ reaction volumes, using 2 units recombinant Taq DNA polymerase per reaction. BSA $\left(160 \mu \mathrm{g} \mathrm{ml}^{-1}\right)$ was added to overcome inhibitory activity (see text). For each reaction, $5 \mu \mathrm{l}$ ancient-bone DNA were used, representing less than $5 \%$ of DNA extracted. Control reactions contained $1 \mathrm{ng}$ modern DNA or no DNA, respectively. Each of the 40 cycles of PCR consisted of denaturation at $93^{\circ} \mathrm{C}$ for $45 \mathrm{~s}$, annealing at $55^{\circ} \mathrm{C}$ for $30 \mathrm{~s}$ and extension at $72{ }^{\circ} \mathrm{C}$ for $60 \mathrm{~s}$. Aliquots $(10 \mu \mathrm{l})$ were electrophoresed on a $1.5 \%$ agarose gel (broad bands under the bands of interest are caused by excess primers). Direct sequencing from low-melt agarose ${ }^{11}$ was performed with primer 4 and the Sequenase sequencing kit (US Biochemical Corp.).

Figure 2 shows these PCR fragments obtained from two of the ancient bone extracts and from modern human DNA.

The 205-bp fragment is part of a mitochondrial gene encoding the protein $\mathrm{NADH}$ dehydrogenase subunit 4 (MTND4). This fragment was amplified from one thirteenth and one seventeenth century bone extract and then sequenced directly from PCR. The two sequences were found to correspond to the published human mitochondrial sequence ${ }^{6}$ but with a $\mathrm{C}$ residue instead of a $\mathrm{T}$ residue at position 11,335, a common mtDNA variant ${ }^{7}$

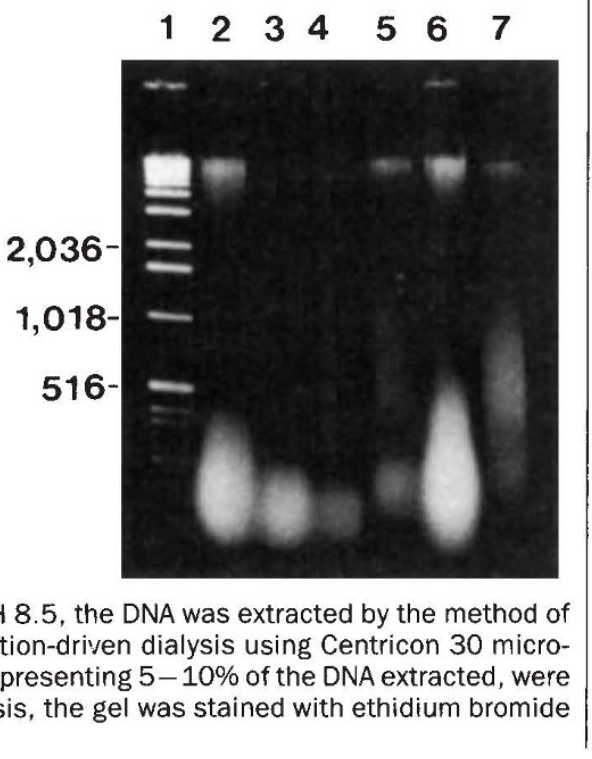

In a recent review ${ }^{8}$, it was stated that it is generally not possible to amplify ancient DNA fragments that are longer than about $150 \mathrm{bp}$, although well-preserved specimens may yield fragments of up to 500 bp. We amplified a 600-bp mtDNA fragment from the 750-year-old bone, but were unable to amplify a 1,100 -bp fragment from ancient extracts (data not shown).

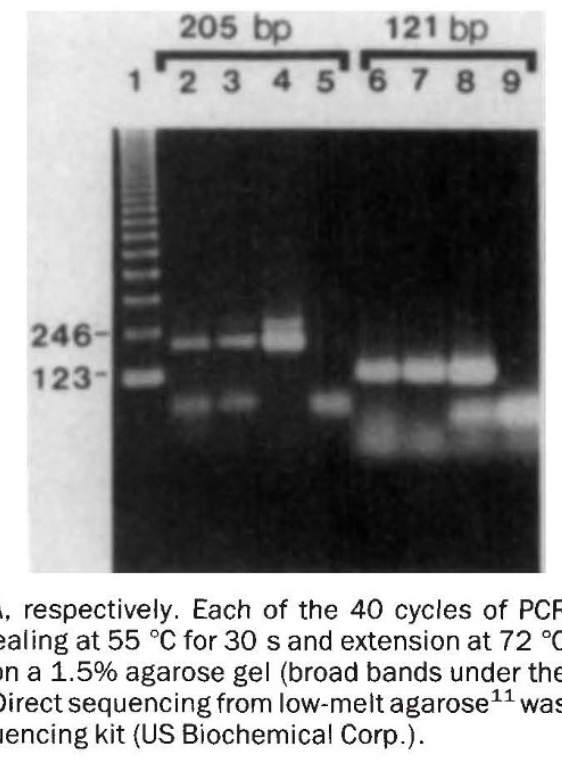

We have shown that it is possible to recover genetic information from ancient skeletal material if contamination by modern DNA is avoided. This work has significant implications for the study of past populations as it provides a source of primary evidence to add to the indirect evidence gained from modern population genetics, and from linguistic, cultural and anthropological sources.

ERIKA HAGELBERG BRYAN SYKES

Institute of Molecular Medicine,

John Radcliffe Hospital,

Oxford OX3 9DU, UK

ROBERT HEDGES

Research Laboratory for Archaeology,

6 Keble Road, Oxford OX1 3QJ, UK

1. Pääbo, S. Nature 314, 644-645 (1985)

2. Higuchi, R., Bowman, B., Freiberger, M., Ryder, O.A. \& Wilson, A.C. Nature 312, 282-284 (1984)

3. Pääbo, S., Gifford, J.A. \& Wilson, A.C. Nucleic Acids Res 16, $9775-9787(1988)$

4. Saiki, R.K. et al. Science 239, $487-491$ (1988)

5. Kwok, S. \& Higuchi, R. Nature 339, 237 - 238 (1989)

6. Anderson, S. et al. Nature 290, 457-465 (1981).

7. Vigilant, L. Stoneking, M. \& Wilson, A.C. Nucleic Acids Vigilant, L., Stoneking, M. \&
Res. 13, 5945-5955 (1988)

8. Pääbo, S., Higuchi, R.G. \& Wilson, A.C. J. biol. Chem 264, 9709-9712 (1989).

9. Maniatis, T., Frisch, E.F. \& Sambrook, J. Molecular Clon ing: A Laboratory Manual (Cold Spring Harbor Laboratory, New York, 1982).

10. Wrischnik, L.A. et al. Nucleic Acids Res. 15, 529-542 (1987)

11. Kretz, K.A., Carson, G.S. \& O'Brien, J.S. Nucleic Acids Res. 17, 5864 (1989)

ACKNOWLEDGEMENTS. We thank J. Poulton for the mtDNA primers and L. Priestley for the DNA sequencing work; the skeletal samples from the English Civil War Cemetery were provided by T. Allen of the Oxford Archaeological Unit and the Wad Mamed sample was donated by the Israel Department of Museums and Antiquities. This work was supported by the SERC. 